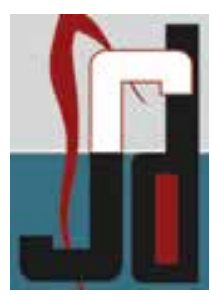

\title{
REVIEW
}

\section{Oral Squamous Papilloma}

Satheesh Kumar.K ${ }^{1}$ KR.Premlal ${ }^{2}$, Sivaramakrishnan.M³ ${ }^{3}$ A.Aroumougam ${ }^{4}$,

ABSTRACT : Oral squamous papilloma refers to the benign proliferation of stratified squamous epithelium, which exhibits a papillary or verrucous exophytic growth on the surface and is composed of benign epithelium and small amount of connective tissue core that is supportive. It is caused by Human Papillomavirus (HPV) types 6 and 11 (HPV 6 and HPV 11) which contain double stranded DNA. 4 in 1000 persons exhibit oral squamous papilloma and is seen in the age group of 30-50 years with equal sex incidence. It is commonly found on the tongue, hard and soft palate, gingival, buccal, labial or lingual mucosa and sometimes area near to the uvula. Clinically, this lesion presents as an exophytic growth with a verrucous, roughened or cauliflower or wart-like surface and is often a solitary lesion. Histologically, it is a benign proliferative exophytic or verrucous growth lined by stratified squamous epithelium with acanthosis and well ordered stratification. Treatment is conservative surgical excision or use of keratinolytic agents.

Key words: Papillomas, Human Papilloma Virus, Benign, Verrucous growth, Koilocytes

\section{Introduction:}

A papilloma (plural: papillomas or papillomata) is defined as a small solid benign tumour of the epithelium with a clear-cut border that projects above the surrounding tissue ${ }^{[1]}$. There are two main types of benign epithelial tumors, depending on the type of the proliferating epithelium: papilloma and adenoma. Papillomas appear in stratified squamous epithelium (skin, oral and pharynx, vagina, cervix, and in areas of squamous metaplasia), urothelium and galactophore ducts. Adenomas are benign tumors of glandular epithelium (parenchyma organs with endocrine and exocrine secretion) and of unistratified mucosa of hollow organs ${ }^{[2]}$.

Oral squamous papilloma is a generic term indicating benign proliferation of stratified squamous epithelium, which results in a papillary or verrucous exophytic growth on the surface. It is composed of benign epithelium and small amount of connective tissue core that is supportive.

\section{Etiology:}

Tomes in 1848 first described squamous pailloma as a localized wart on the gingiva. It is caused by Human Papillomavirus (HPV) types 6 and 11 (HPV 6 and HPV 11) which is less virulent and with low infectivity rate.
The pathogenesis lies in that the viral DNA which is double stranded integrates with the host DNA leading to the development of papilloma.

\section{Incidence and Occurrence in Oral Cavity:}

Among the mucosal mass in the oral cavity, squamous papilloma has fourth common incidence rate. 4 in 1000 persons exhibit oral squamous papilloma and accounts for 3-4\% among biopsied specimens of oral cavity soft tissue lesions. It is the most common papillary lesion of oral mucosa and is usually reported in the age group of 30-50 years with equal sex incidence (slight male predilection in some studies). Some researchers point out among children; it comprises $7-8 \%$ of growth or mass in the oral cavity and whites are more affected than black population. It is commonly found on the tongue, hard and soft palate, gingival, buccal, labial or lingual mucosa and sometimes area near to the uvula. It is considered to be the most common soft tissue mass to arise in the soft palate. ${ }^{[3][4]}$

There are few significant differences between papilloma of the oral cavity and papilloma of other body parts. Oral squamous papilloma though benign in nature, has a higher neoplastic potential compared to other papillomas. They have a higher frequency of occurrence and recurrence (if not properly excised) is significantly higher in comparison. ${ }^{[5][6]}$ 


\section{Clinical features:}

Clinically, this lesion presents as an exophytic growth with a verrucous, roughened or cauliflower or wartlike surface and is often a solitary lesion. The surface shows numerous small finger-like projections or may be blunted. It is a pedunculated lesion but can be sessile occasionally. It is often well circumscribed. It is mostly painless and appears as a white or pink lesion depending on the thickness of keratinization. Sometimes the surface appears reddened due to trauma. The size is most often small measuring a few millimetres to less than $1 \mathrm{~cm}$ in diameter but sometimes large lesions can be seen (Fig-1) ${ }^{[7][8][9]}$.

\section{Clinical Differential Diagnosis: ${ }^{[9]}$}

1. Verruca vulgaris

2. Condyloma acuminatum

3. Verruciform xanthoma

4. Multifocal epithelial hyperplasia

5. Nevus unius lateris

6. Acanthosis nigrans

7. Focal dermal hypoplasia (Gorlin-Goltz syndrome)

\section{Gross features: ${ }^{[4]}$}

The gross specimen appears whitish pink in color and exhibits finger like or cauliflower like surface projections. Majority of the lesions are lesser than 1 $\mathrm{cm}$.

\section{Histopathology:}

Histologically, it is a benign proliferative exophytic or verrucous growthlined by stratified squamousepithelium with acanthosis and well ordered stratification. Oliveira et al proposed strict histopathological criteria for squamous papilloma includes finger-like projection of stratified squamous epithelium with normal maturation of cells (Fig-2), presence of hyperparakeratosis in epithelium, Koilocytosis as the result of perinuclear cytoplasmic vacuolisation of spinous cells which produce perinuclear clear/ pale halos and pyknosis, occasionally basilar hyperplasia (Fig-3). The connective tissue is fibrovascular in nature which might show inflammation ${ }^{[7][10][11]}$.

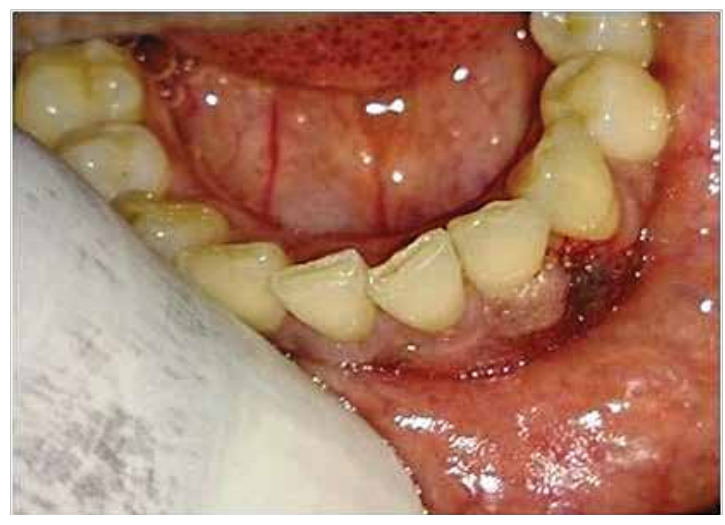

Fig-1: Intra oral picture shows exophytic growth in relation to 32,33 region

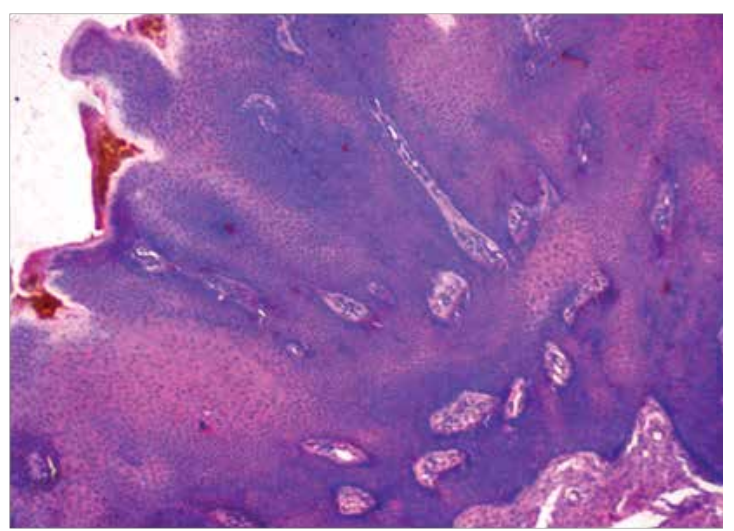

Fig-2: Acanthotic stratified squamous epithelium with blunt exophytic projections [H \& E, 4x]

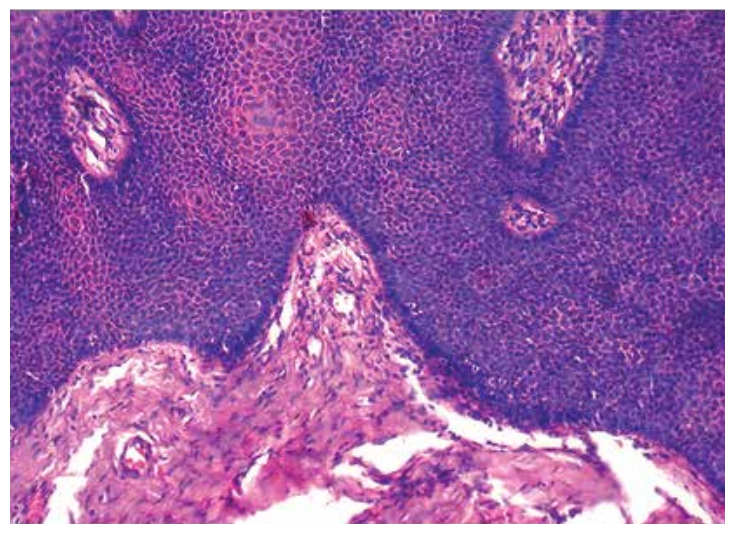

Fig-3: Dyskeratosis evident in the epithelium [H \& E, 10x]

\section{Laboratory Diagnosis:}

Detection of the virus by conventional biopsy is very difficult as only changes caused by the virus can be observed. Electron microscopic analysis shows viral particles. The other methods of detection are in situ hybridization, immunohistochemistry and polymerase chain reaction (PCR) techniques. 


\section{Immunohistochemistry: ${ }^{[12]}$}

P53 (TP53 or tumor protein), PCNA (Proliferating cell nuclear antigen), CD44 (cell-surface glycoprotein involved in cell-cell interactions, cell adhesion and migration) and Bcl-2 (B-cell lymphoma 2) are overexpressed in case of malignant transformation and in papillomas with epithelial dysplasias.

\section{Treatment}

The typical treatment for squamous papilloma is surgical excision with recommended clearance of $1 \mathrm{~mm}$ margin at base to the depth of the submucosa. Lactic acid containing keratinolytic agents and liquid nitrogen can be used to excise very small lesions ${ }^{[13]}$.

\section{References :}

1. Dorland W. Dorland's Pocket medical dictionary. Philadelphia: Elsevier; 1982.

2. Prashant P. Jaju, Prashant V. Suvarna, Rajiv S. Desai. Squamous Papilloma: Case Report and Review of Literature. Int J Oral Sci. 2010;2(4):222-225.

3. StinaSyrjanen. Human papillomavirus infections and oral tumors. Med MicrobiolImmunol. 2003;192:123-128.

4. Barnes L. Pathology and genetics of head and neck tumours. Lyon: IARC Press; 2005.

5. Koichi Mishima, Yoshiki Nariai, Seiji Obara, Yasuro Yoshimura. Human Papilloma virus in Oral Squamous Papilloma and Verrucous Carcinoma: Evaluation Using in Situ Polymerase Chain Reaction Detection. Asian J Oral Maxillofac Surg. 2002;14:95ロ99.
6. AN K, R R, H HK. Larg squamous papilloma o buccal mucosa.JCR 2012;2:110-113

7. Regezi J, Sciubba J, Jordan R. Verrucal-Papillary lesion. In: Oral pathology clinical pathological correlations. 4th edition. St. Louis, Mo.: Elsevier/Saunders; 2003. P. 143.

8. Rajendran R, Sivapathasundaram B. Benign and malignant tumors of oral cavity. In: Shafer's textbook of Oral Pathology.6th edition. Noida, New Delhi: Elsevier; 2009. P. 81.

9. Neville, Damm, Allen, Bouquot. Epithelial pathology. In: Oral and Maxillofacial Pathology. 2nd edition. New Delhi: Elsevier/Saunders; 2014. P. 316.

10. Bao Z, Yang X, Shi L, Feng J, Liu W, Zhou Z. Clinicopathologic features of oral squamous papilloma and papillary squamous cell carcinoma: a study of 197 patients from eastern China. Annals of Diagnostic Pathology. 2012;16(6):454-458.

11. Abbey LM, Page DG, Sawyer DR. The clinical and histopathologic features of a series of 464 oral squamous cell papillomas. Oral Surg Oral Med Oral Pathol. 1980 May;49(5):419-28.

12. Reszeć J, Sulkowska M, Famulski W, Guzińska-Ustymowicz $\mathrm{K}$, Sulkowski S. The expression of tumorigenesis markers in oral papilloma. Pol J Pathol. 2002;53(4):195-200.

13. Marx RE, Stern D. Oral and Maxillofacial Pathology: A Rationale for Treatment. Hanover Park, Ill.: Quintessence Publishing; 2003: 


\section{Address of Correspondence}

Dr.Satheesh Kumar.K

Postgraduate student

Oral Pathology \& Microbiology

Indira Gandhi Institute of Dental Sciences

Sri Balaji Vidyapeeth University

Cell: 9894101319

E-mail Id: joinsatheesh@yahoo.co.in

\section{Authors:}

${ }^{1}$ Postgraduate student, Oral Pathology \& Microbiology, Indira Gandhi Institute of Dental Sciences, Sri Balaji Vidyapeeth University

${ }^{2}$ Reader, Oral Pathology \& Microbiology, Indira Gandhi Institute of Dental Sciences, Sri Balaji Vidyapeeth University

${ }^{3}$ Senior Lecturer, Oral Pathology \& Microbiology, Indira Gandhi Institute of Dental Sciences, Sri Balaji Vidyapeeth University

${ }^{4}$ Postgraduate student, Oral Pathology \& Microbiology, Indira Gandhi Institute of Dental Sciences, Sri Balaji Vidyapeeth University

\section{How to cite this article :}

Satheesh Kumar.K, KR.Premlal, Sivaramakrishnan.M, A.Aroumougam. Oral Squamous Papilloma. Journal of Scientific Dentistry, 2017;7(1):46-49

Source of Support : Nil, Conflicts of Interest : None declared 